\title{
Towards a Model of Technology Adoption: A Conceptual Model Proposition
}

\author{
Pat Costello and Rob Moreton \\ School of Computing and IT, \\ University of Wolverhampton, \\ Wolverhampton, U.K.
}

\begin{abstract}
A conceptual model for Information Communication Technology (ICT) adoption by Small Medium Enterprises (SMEs) is proposed. The research uses several ICT adoption models as its basis with theoretical underpinning provided by the Diffusion of Innovation theory and the Technology Acceptance Model (TAM). Taking an exploratory research approach the model was investigated amongst 200 SMEs whose core business is ICT. Evidence from this study demonstrates that these SMEs face the same issues as all other industry sectors. This work points out weaknesses in SMEs environments regarding ICT adoption and suggests what they may need to do to increase the success rate of any proposed adoption. The methodology for development of the framework is described and recommendations made for improved Government-led ICT adoption initiatives. Application of the general methodology has resulted in new opportunities to embed the ethos and culture surrounding the issues into the framework of new projects developed as a result of Government intervention. A conceptual model is proposed that may lead to a deeper understanding of the issues under consideration.
\end{abstract}

\section{Introduction}

For many SMEs innovation is not about 'blue-sky' research and leading edge technology but about the adoption of technology that will allow new processes to be employed by the company that are innovative for them (Mehrten, 2001). The decision to adopt technology brings into play a myriad of both business and technology issues that can be overwhelming for an SME. Many models have examined Electronic Data Interchange (EDI) adoption (Jackson and Sloane, 2007) and the transferability of these models from EDI to Internet but the testing of the model's adoption into all technologies has been less well examined. Academicians and governments have attempted for many years to address the issue of increasing efficient adoption of ICT and this quest has been gathering pace in recent years, fuelled by work such as that of Sheppard et al.(2007). Sheppard determined a link between efficient and effective technology adoption and increases in productivity. This paper attempts to take this work a step further by developing a model for adoption based on earlier models devised by other researchers in this area. The research study developed to address the question: Is it possible to develop an overarching model of ICT adoption using current models which can be applied whatever the technology? 
In spite of many years of research in the area of ICT adoption, progress is slow mainly due to the myriad of complexities in the subject area. Investment by the United Kingdom (UK) Government continues, albeit regionally and not on a national scale. Where there is investment, it focuses on a single technology and does not address the concerns surrounding the environment within which SMEs operate. There is a need to embed the culture and skills required within SMEs and raise awareness regarding ICTs potential which may aid any future adoption of technology. SME engagement is crucial as they form an important part of the business community and have the ability to impact in a major way on customers and suppliers. Large organisations that have turned to electronic means of communication, for example, will often find that the 'bottleneck' in the supply chain will be an SME who is an immature technology user (Costello et al., 2006).

Poon and Huang (in Ai-Qirim, 2003) describe the need for a more integrated approach to ICT adoption research stating that a continuation of the single approach in studies leaves the field with yet more disparate conclusions. The inherent problem with the multi-faceted approach called for by Poon and Huang is the depth of the study which if broad in approach can be shallow in content. However, they then call for the need for triangulation in 'method, theory, measures or observers'. The research approach recommended by Poon and Huang was integrated into the research reported here.

\section{Government Intervention in the Adoption Process}

Academics and governments have previously attempted to address the issue of increasing efficient adoption of ICT and this issue is gathering pace in the West Mildlands (WM) UK fuelled by the work of Sheppard et al., (2007). This determines a strong causal link between efficient and effective technology adoption and increases in $\mathrm{GVA}^{1}$. However, in spite of many years of work in the field of ICT adoption by scholars, progress is slow, as complexities inherent in this area make it a difficult research topic. Investment by Government also continues in an attempt to increase the adoption of ICT by SMEs as this has been shown to be a very effective way of increasing GVA. However, much of the work supported by Government involves a single technology and does not address the concerns surrounding the environment within which SMEs operate which may have an adverse effect on the success of adoption and also limits future take up.

In spite of attempts by the Government, the small business sector still has problems and is often suspicious of those that work to help them (Bennett and Robson, 1998). There is now a plethora of government funded support services available for SMEs and this in itself can be confusing for owner-managers. Support to adopt ICT is often superficial, aimed at end users and of limited use to companies whose core business is ICT. Policy makers need to address the benefits for SMEs, rather than the need to hit government targets (Culkin and Smith, 2000) and indeed be concerned with the SMEs need and not with personal career development (Mercer, 1996). It has been suggested

${ }^{1}$ Gross Value Added (GVA) measures contribution to the economy of each individual producer, industry or sector in the United Kingdom. GVA + taxes on products - subsidies on products $=$ GDP http://www.statistics.gov.uk/cci/nugget.asp?ID=254 accessed 11/10/2007. 
that many intervention projects address the needs of the policy makers' career rather than the intervention itself (Culkin and Smith, 2000); although that is an understandable concern given the often transient nature of job roles in this area.

The way Government initiative targets are set and defined point towards a 'generalist' view of SMEs (Martin \& Matlay, 2001). In work done by MacGregor and Vrazalic (2005) eBusiness was recognised as a major source of competitive advantage and they state that this now means that Governments worldwide have recognised this and are creating funding schemes and initiatives to facilitate e-Commerce adoption in small businesses. There have also been many attempts by authors to categorise barriers and enablers in this major area of concern. The Department for Trade and Industry (DTI) a United Kingdom (UK) central government department who recently changed its' name to the Department for Business, Enterprise and Regulatory Reform (BERR) published the governments 'adoption ladder' for their UK online initiative. The model underpins much of the understanding around the area of ICT adoption in SMEs (Sergeant 2000 cited in Martin and Matlay, 2001). Unfortunately, the only flexibility built into the model is to imply that not all businesses will start at stage one. However there is no flexibility for significant differences in size, sector, ethnicity, gender, human resources, financial resources, level of internationalisation. Neither is there a place for the entrepreneurial or innovative skills of owner-managers in this model. Martin \& Matlay (2001) claim there is a lack of 'empirically rigorous data and focused research' on the topic of ICT adoption by small companies. Stating that the DTI literature claims that the adoption of new technologies is essential to survival and growth is based upon sweeping generalisations.

There is much evidence to suggest that linear models of development and adoption are inappropriate for SMEs and tend to oversimplify complex issues (Kai-Uwe Brook, 2000). Kai-Uwe (2000) refer to a paucity of academic research in this area and claim that further research is necessary in order to develop 'real understanding' of ICT adoption by SMEs. These findings are an echo of earlier research work by Lauder and Westhall (1997), Iacovou et al. (1995) and Blackburn and Athayde (2000). It is a concern that a blanket approach to investment of this kind informs government in this area as it may be inappropriate given that SMEs are created and 'die' in vast quantities every year. Many organisations involved in projects which attract Government funding to help establish their ICT, are not necessarily still 'established' a few years later. This creates the impression that the money has not been of any long term help. Although without statistics to show how many SMEs who take part in a particular project are still in business a number of years later, no assumptions can be made. Neither can it be established if the ICT project itself was a contributor to this failure. There is a strong need for impartial advice independent from vendors. Many need practical help in the form of trusted ICT Consultancy (Harindranath et al., 2007, Costello et al., 2008) as well as grants or loans.

Since the demise of the UK Online initiative, a government funded project to encourage businesses to use the Internet, the only government entity playing a national role in the ICT policy arena is e-skills UK. Its aim is to work with businesses to improve competitiveness and productivity by bringing together employers, educators and government, uniting them for a common, employer-led agenda for action on skills. In spite of the evidence of GVA increases there is currently no national level strategy to increase adoption of ICT by SMEs. 


\section{EDI, eBusiness and Internet Adoption Models}

The theoretical underpinning of much of the work in this field is based on work by Rogers (1965 in Rogers, 2003) in his book Diffusion of Innovation which sets the scene and provides much of the basis upon which work regarding technology acceptance is grounded. Rogers' (1965) work categorised adopters of new innovations as innovators $(2.5 \%)$, early adopters $(13.5 \%)$, early majority (34\%), late majority (34\%) and laggards (16\%) based on a bell curve. The study discussed the conviction that an innovation decision was based on a cost-benefit analysis and that people would adopt if they believed that the innovation could produce some relative advantage to the idea it replaced. Critics have remarked that it attempts to explain a very complex reality in too simplified a fashion. Nonetheless; this theory has remained as a starting point upon which much IS research in this area is based. Since this early work, research has consistently found that relative advantage (perceived need) is an important issue in the adoption decision (Bradford and Florin, 2003).

Fishbein and Ajzen's (1975) theory of reasoned action provided insight into the reasoning behind the behaviour of individuals and posited that a person's attitude towards behaviour (attitudes) and how they think others will view that behaviour (subjective norm) forms the basis upon which they intend to behave (behavioural intention). It was this work that formed the basis for the Technology Acceptance Model (TAM) developed by Davis et.al. (1989) and Bagozzi et al. (1992). Their work replaced the two attitude measures with two technology acceptance measures; ease of use and usefulness. Both models assume that an individual is free to act as they wish once they form the intent to act. In the real world this is not always the case as there are often numerous constraints. Work on the diffusion of innovation has also taken into account perceived ease of use. Tornatzky and Klein (1982) looked at the relationship between compatibility, relative advantage and complexity and found that these had the most significant link to adoption. Much work has centred on testing these models over the last few decades including looking at the validity of research instruments used in the original work. Venkatesh and Davis (2000) developed the work to include perceived usefulness and usage intentions; this model was referred to as TAM2. However, critics of TAM conclude that a limitation of the model is that it excludes influences on personal behaviour, economic factors and outside influences (Van Akkeren and Cavaye, 1999). TAM was subsequently developed into the Unified Theory of Acceptance and Use of Technology (UTAUT) (Venkatesh et.al., 2003).

Many ICT adoption models have been tested in large companies only (Chwelos et al., 2001, Jackson and Sloane, 2005, Levy and Powell, 2005, Lefebvre and Lefebvre, 1996) and many revolve around adoption of EDI, Internet and eBusiness. The main problem identified from the literature is defining the factors that impact the successful adoption of ICT. Many researchers have found that these models are transferable in the realm of communication technologies. There are, however, difficulties with transferring the models from large companies to SMEs as decision-making structures are incomparable. Neither have these models been tested and applied to successful adoption of all ICT infrastructures rather than just a specific technology.

However, the advent of the Internet era has allowed small companies to employ communication on a par with EDI for a fraction of the cost. Hence many models have been developed for the adoption of Internet and eBusiness. Sarosa and Zowghi 


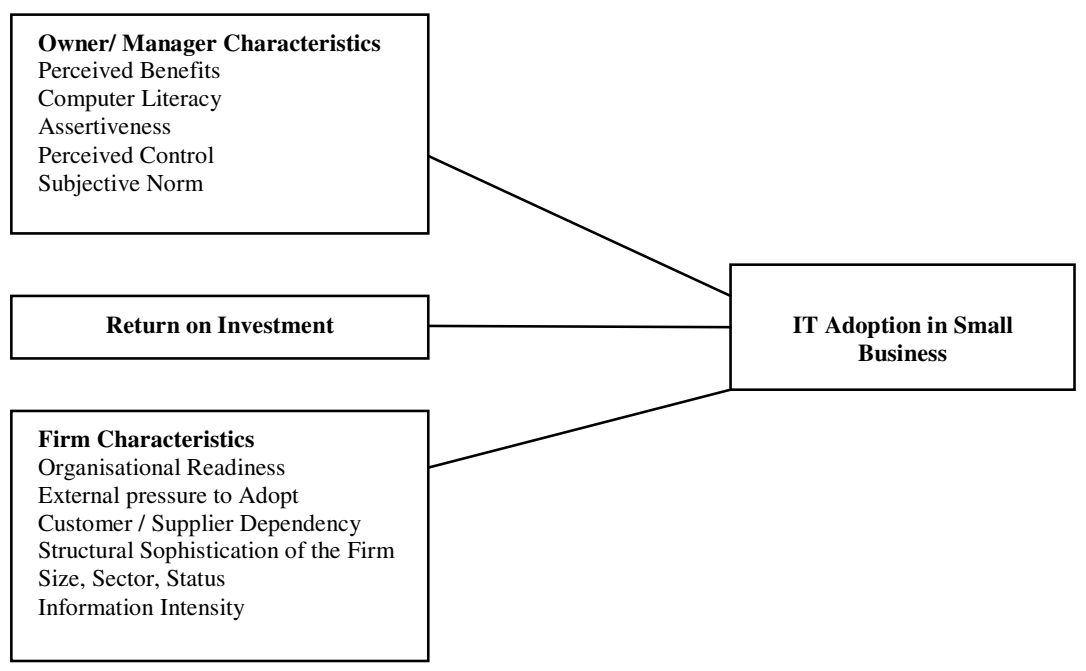

Fig. 1. Factors affecting ICT adoption in SMEs (Van Akkeren and Cavaye 1999)

(2003) state that research to date has concentrated on identifying drivers and barriers to adoption of ICT and there is still a lack of frameworks or models that actually guide SMEs in the adoption process. The most frequently asked question by any SME is how to adopt successfully. There is a very small body of academics examining adoption models at this time (Levy et.al., 2005b, Van Akkeren and Cavaye, 1999) especially in the area of SMEs. The fact that many factors are similar in so many models may indicate that the technology to be adopted is irrelevant. Levy (2005a) also indicated that industry sector is irrelevant although research for this paper examined one specific sector (ICT) which may be assumed to be more capable than other sectors and proficient at supporting others.

Van Akkaren et.al. (1999) study of the literature supports the conviction that in SMEs, issues around adoption can be divided into factors regarding the ownermanager characteristics, firm characteristics and other factors, including the need for an owner-manager to realise a return on investment (ROI). Fig. 1 shows the factors identified by that study as affecting adoption in small businesses. The study also claims that there are probably more factors than this as yet to be uncovered by future research and that current models do not include ROI. Research carried out by Jackson and Sloane (2007) shows that more subtle issues such as organisation culture and human resources have a major impact on the adoption of new systems and are therefore included in their model for e-Commerce. There is often an underlying assumption by SMEs that simply adopting new technology will automatically produce benefits for the company (Costello et al., 1999). In particular, SMEs tend to believe that the technology itself will improve business processes and do not always address the process improvements, trying instead to automate existing ones (Husein et al., 1999).

Mehrten et al. (2001) demonstrated that the CEO has a significant role in ICT adoption in SMEs, especially if the CEO is innovative and knowledgeable about ICT. This model was again developed from existing studies and had as its grounding the 
Table 1. Summary of Adoption Factors from literature

\begin{tabular}{|c|c|c|}
\hline Source & $\begin{array}{l}\text { Model Devel- } \\
\text { opment }\end{array}$ & Factors \\
\hline $\begin{array}{l}\text { Levy and } \\
\text { Powell } \\
(2005)\end{array}$ & $\begin{array}{l}2 \text { Surveys : } \\
343 \text { and } 21 \\
\text { SMEs in WM }\end{array}$ & Entrepreneur, Firm, Strategy \\
\hline $\begin{array}{l}\text { Merheten et al. } \\
\text { (2001) }\end{array}$ & $\begin{array}{l}7 \text { SMEs Case } \\
\text { Studies (Australia) }\end{array}$ & $\begin{array}{l}\text { Organisational Readiness, } \\
\text { External Pressures, Strategy, } \\
\text { Perceived Benefits. }\end{array}$ \\
\hline $\begin{array}{l}\text { Storey } \\
(1994)\end{array}$ & $\begin{array}{l}\text { Longitudinal } \\
\text { survey on broad } \\
\text { SME issues }\end{array}$ & $\begin{array}{l}\text { Starting resources of the entrepreneur, } \\
\text { The Firm, The Strategy. }\end{array}$ \\
\hline $\begin{array}{l}\text { Grandon et al. } \\
(2004)\end{array}$ & $\begin{array}{l}9 \text { Literature } \\
\text { sources, } 100 \text { email } \\
\text { surveys }\end{array}$ & $\begin{array}{l}\text { Organisational Readiness, } \\
\text { External Pressure, Perceived } \\
\text { Usefulness + Perceived Ease of Use }\end{array}$ \\
\hline $\begin{array}{l}\text { Van Akkeren and } \\
\text { Cavaye (1999) }\end{array}$ & $\begin{array}{l}6 \text { Literature } \\
\text { sources - no } \\
\text { survey }\end{array}$ & $\begin{array}{l}\text { Owner manager characteristics, Firm } \\
\text { Characteristics. }\end{array}$ \\
\hline $\begin{array}{l}\text { Rashid and } \\
\text { Al-Qirim } \\
\text { (2001) }\end{array}$ & $\begin{array}{l}3 \text { Literature } \\
\text { sources - no } \\
\text { survey (New } \\
\text { Zealand) }\end{array}$ & $\begin{array}{l}\text { Individual factors, Organisational } \\
\text { factors, Environmental factors, } \\
\text { Technological factors. }\end{array}$ \\
\hline $\begin{array}{l}\text { King-Turner and } \\
\text { Bonnett } \\
(2005)\end{array}$ & $\begin{array}{l}60 \text { SMEs surveyed } \\
\text { in WM }\end{array}$ & $\begin{array}{l}\text { Personal factors, Economic Factors } \\
\text { (cost and resource), Environmental } \\
\text { factors, Relevant solution. }\end{array}$ \\
\hline
\end{tabular}

work of Lefebvre and Lefebvre (1996) and Thong and Yap (1995). Merhten's belief was previously identified in the work of Van Akkeren and Cavaye (1999) above. The research uncovered 3 issues that are prevalent in EDI adoption research: perceived benefits, organisational readiness and external pressures. These elements are then used to test ICT adoption issues. It was also revealed in this study that there is a need to have the skills in house as this supports the users during implementation. Merhten claims that further research could determine if the model was transferable to other technologies.

Storey's (1994) study over a three-year period between 1989 and 1992, completed work that helped form the basis of much of today's work with SMEs. His work spanned 10,000 SMEs in the UK and had a significant influence on much of the decade's policy making. The model developed which is of interest to this study, included 
factors influencing growth in small firms (Storey, 1994). In this model each of the three factors of the entrepreneur, the firm and the strategy are defined by a number of issues, the most significant of these were incorporated into the research for this paper.

Levy et al.(2005a) model was adapted from Storey's (1994) and a development of this model was applied to West Midlands (WM) UK SMEs. Their work on Internet adoption determined that business growth is a key driver in Internet adoption and therefore is a sound basis on which to develop a model. They also describe the SME market as investing in information systems at start up and then no further development until the business outgrows its first purchase. Levy et al. (2005b) claim that many of the drivers can be described as perceived benefits and many of the inhibitors are recognized as being due to management limitations.

Grandon and Pearson (2004) analysed ten ICT adoption models to determine the main ICT adoption factors and found that many of the same issues recurred throughout the literature. They summarised these factors into organisational readiness, external pressure, perceived ease of use and perceived usefulness. They determined a causal link between perceived strategic value of e-business and e-business adoption. The collated factors from the research from other authors represented the output from more than 1,700 small companies. The factors were amalgamated into a model which was tested via survey on a further 100 companies. The survey found that a positive change in attitude towards adoption of the technology based on the 'impression' of its strategic value to the firm was necessary to successful adoption.

Rashid and Al-Qirim (2001) considered the specific difficulties of SMEs and produced a considerably simplified model for these, by building on previous work by Thong and Yap (1995) and Premkuma and Roberts (1999). They concluded that issues such as the individual characteristics of the owner manager are essential in successful adoption of e-Commerce in SMEs and that competition also significantly influences adoption. Their findings also highlighted that often it is lack of knowledge of the technology that is the main barrier to adoption and the acknowledgement of the strategic importance of the technology usually came from the larger companies in the sample.

A subsequent model was developed and applied to 60 SMEs in the WM UK (KingTurner and Bonnett, 2005). The survey was conducted to determine factors in adopters and non-adopters of Open Source Software (OSS). The model developed was based on the work of Rashid and Al-Qirim (2001) but added other factors that had been evident during the course of regional work with SMEs. The main reasons given by the companies in their survey for adoption were Economic Factors, both the cost and the resources, which underpins the research indicated by Locke (2004) who found that hardware was considered to be the most significant cost and consideration by SMEs.

A summary of the models discussed here is provided in table 1, these were used to underpin the new model based on Van Akkeren and Cavaye (1999) framework which is proposed for the adoption of technology infrastructure in this study.

\section{Methodology and Development of a New Model}

A model was developed from those in table 1 above and explored amongst the SME sector in the WM, UK to ascertain if the factors could be applied to any technology. 
Especially as many adoption models overlap or complement each other (Van Akkeren and Cavaye, 1999) and most involve at least some factors that are directly comparable. This research further explores the factors around ICT infrastructure adoption; looking at all technology purchases by SMEs by examining the last significant purchase the company made, with the significance being defined by the owner-manager. Table 2 shows a summary of the elements from the models used in the study. This was verified and supplemented by factors from the extensive literature review.

Table 2. Summary of Factors involved in ICT adoption for SMEs

\begin{tabular}{|c|c|c|c|c|c|c|}
\hline Source: & $\begin{array}{l}\text { Personal } \\
\text { Factors }\end{array}$ & The Firm & $\begin{array}{l}\text { Organisa- } \\
\text { tional } \\
\text { readiness }\end{array}$ & $\begin{array}{l}\text { External } \\
\text { Pressures }\end{array}$ & $\begin{array}{l}\text { Perceived } \\
\text { Value }\end{array}$ & Strategy \\
\hline $\begin{array}{l}\text { National } \\
\text { B2B } \\
(2005)\end{array}$ & $\begin{array}{l}\text { Personal } \\
\text { factors }\end{array}$ & & $\begin{array}{l}\text { Economic } \\
\text { Factors } \\
\text { (cost and } \\
\text { resource) }\end{array}$ & \multicolumn{2}{|l|}{$\begin{array}{l}\text { Environmental } \\
\text { factors }\end{array}$} & \multirow[t]{2}{*}{$\begin{array}{l}\text { Relevant } \\
\text { solution }\end{array}$} \\
\hline $\begin{array}{l}\text { Rashid } \\
\text { and } \\
\text { Al-Qirim } \\
(2001)\end{array}$ & $\begin{array}{l}\text { Individual } \\
\text { factors }\end{array}$ & & $\begin{array}{l}\text { Organisa- } \\
\text { tional } \\
\text { factors }\end{array}$ & $\begin{array}{l}\text { Environ- } \\
\text { mental } \\
\text { factors }\end{array}$ & \multirow[t]{2}{*}{$\begin{array}{l}\text { Technologica } \\
\text { (innovation) } \\
\text { factors }\end{array}$} & \\
\hline $\begin{array}{l}\text { Levy and } \\
\text { Powell } \\
(2005)\end{array}$ & \multirow{2}{*}{\multicolumn{2}{|c|}{$\begin{array}{l}\text { Entrepreneur Firm } \\
\text { s }\end{array}$}} & & & & \multirow[t]{2}{*}{ Strategy } \\
\hline $\begin{array}{l}\text { Merhetens } \\
\text { et al. } \\
(2001)\end{array}$ & & & $\begin{array}{l}\text { Organisa- } \\
\text { tional } \\
\text { Readiness }\end{array}$ & $\begin{array}{l}\text { External } \\
\text { Pressures }\end{array}$ & $\begin{array}{l}\text { Perceived } \\
\text { Benefits }\end{array}$ & \\
\hline $\begin{array}{l}\text { Storey } \\
\text { (1994) }\end{array}$ & \multirow{2}{*}{\multicolumn{2}{|c|}{ Entrepreneur Firm }} & & & & \multirow[t]{2}{*}{ Strategy } \\
\hline $\begin{array}{l}\text { Grandon } \\
\text { et al. } \\
(2004)\end{array}$ & & & $\begin{array}{l}\text { Organisa- } \\
\text { tional } \\
\text { Readiness }\end{array}$ & $\begin{array}{l}\text { External } \\
\text { Pressure }\end{array}$ & $\begin{array}{l}\text { Perceived } \\
\text { Usefulness }+ \\
\text { Perceived } \\
\text { Ease of Use }\end{array}$ & \\
\hline $\begin{array}{l}\text { Van } \\
\text { Akkeren } \\
\text { and } \\
\text { Cavaye } \\
\text { (1999) }\end{array}$ & $\begin{array}{l}\text { Owner } \\
\text { manager } \\
\text { characteris- } \\
\text { tics }\end{array}$ & $\begin{array}{l}\text { Firm } \\
\text { Characteris } \\
\text { tics }\end{array}$ & $\begin{array}{l}\text { Firm } \\
\text {-Characteris } \\
\text { tics }\end{array}$ & $\begin{array}{l}\text { Firm } \\
\text {-Characteris- } \\
\text { tics }\end{array}$ & $\begin{array}{l}\text { Owner Man- } \\
\text { ager } \\
\text { Characteris- } \\
\text { tics }\end{array}$ & $\begin{array}{l}\text { Firm } \\
\text { Characteris- } \\
\text { tics }\end{array}$ \\
\hline
\end{tabular}

It was ascertained that firm characteristics can include, organisational readiness, external pressure to adopt, customer/supplier dependency, structural sophistication of the firm, sector and status (Grandon et.al., 2004, Levy et al., 2005, Van Akkeren and Cavaye, 1999, Thong and Yap, 1995, Rashid et al., 2001, Mehrten et al., 2001, 
Storey, 1994). In this study, the sector is not considered as the survey was completed in one sector; although there are indications from Sheppard (2007) that the ICT sector is important and that this sector may embrace ICT more readily than others. However, this study looks at whether the ICT sector is in fact embracing technology for use within the business in a sophisticated way or if they do not 'practice what they preach'. The structural sophistication of the firm is not measured, instead the evidence from the literature review shows that companies become more structurally complex as they grow and that the larger the organisation the more likely they are to consider strategy, hence this element is captured via strategy. External pressures are examined and the pressure of customer and/or supplier noted. Organisational readiness examines the technology already in place within an organisation and their readiness to adopt. The factors which represent the firm's characteristics are encapsulated into Strategy, organisational readiness, the firm and external pressures.

The owner-manager characteristics can include perceived benefits, computer literacy, assertiveness, perceived control and subjective norm (Grandon et.al., 2004, Levy et al., 2005, Van Akkeren and Cavaye, 1999, Thong and Yap, 1995, Iacovou, 1995, Rashid et al., 2001, Mehrtens et al., 2001, Storey, 1994). These are seen in perceived value and personal factors within the model developed here. Given that the majority $(69 \%)$ of the companies are micro (less than 10 employees), computer literacy is collated through the presence of a skilled ICT professional within the company and the owner-manager themselves as a technology champion within an ICT company. It is also considered within the implementation issues explored since skills levels may account for adoption problems experienced post adoption. Assertiveness, perceived control and subjective norm are not explored in any detail in this study as these were seen to be part of the sociological and psychological aspects and thus need further research outside of the scope. Although this split of owner-manager characteristics and firm characteristics is demarcated in the work of many researchers, it is often not as easy to clearly differentiate between these areas. For example the SME sophistication may be due to the owner-manager or the level of technology within the firm. The organisational readiness can be as much linked to the strategy or lack of strategy in the company as it can be to the owner-manager attitude to adoption.

Following an extensive literature survey, three pilot case studies were conducted at the start of the research to gain an understanding of the factors important to small companies when adopting ICT. This was followed by a sample survey of eight companies to further refine the model and also the survey instrument. This evidence was translated into the model which formed the basis of a survey of 206 SMEs in the ICT sector.

The approach to the survey was predominately qualitative and a questionnaire was designed that collected a limited amount of quantitative data. The questions were split into 4 sections: Company Background, Current ICT infrastructure, ICT Investment and Impact on Business Performance. The questionnaire was delivered in a semi-structured interview approach with $83 \%$ conducted by face-to-face interviews and $17 \%$ by telephone interview. The large number (200) of respondents was a challenge and the subsequent data was read several times and then categorised and encoded. Two techniques were involved in sampling the target population; the first was probabilistic in that companies attending ICT events throughout the local region were approached during the events and asked to take part in the research. This then led to snowball sampling as 
having gained the trust of the owner-manager of one company; they would often give details of associates, partners or collaborators who would also be willing to participate. From the 206 companies only $6 \%$ of responses were 'spoiled'; this left $69 \%$ micro companies (less than 10 employees), 17\% small companies (less than 50 employees) and $8 \%$ medium companies (less than 250 employees).

Table 3. Individual elements in the new model development

\begin{tabular}{lcl}
\hline Category & $\begin{array}{l}\text { No of models theElements } \\
\text { issue appears in: }\end{array}$ \\
\hline Personal Factors & 4 & $\begin{array}{l}\text { Educational experience, knowledge of } \\
\text { IT }\end{array}$ \\
The Firm & 3 & $\begin{array}{l}\text { Age, size, sector. } \\
\text { Organisational } \\
\text { readiness }\end{array}$ \\
& 4 & $\begin{array}{l}\text { Advice sought, Internal pressures, } \\
\text { Specialist skills in company, } \\
\text { implementation issues } \\
\text { (often linked to skills). }\end{array}$ \\
Perceived Value & 5 & $\begin{array}{l}\text { Advantage over traditional methods, } \\
\text { Measures of success, evaluation, } \\
\text { perception of success. } \\
\text { Identification of external pressures in } \\
\text { the decision making process, } \\
\text { influences on the purchase. } \\
\text { The level of decision making } \\
\text { undertaken, reason for purchase, } \\
\text { significance of purchase. }\end{array}$ \\
Strategy & 5 & 4
\end{tabular}

The categories and elements derived from this study are shown in table 3 . The new model (table 3) encompasses 'measures of success' or return on investment (ROI) within the perceived value section. This element in an SME environment could be seen as the single most important factor and has been absent from prior models (Van Akkeren and Cavaye, 1999). It was encompassed in this way to include a pre-evaluation check (perceived benefits from previous models) and a post evaluation element not seen before. SME owner-managers have significant influence on ICT adoption and success rates; it is their 'perception' of the value to the company that is often either the inhibitor or the driver for the adoption. Previous models have looked at 'perceived usefulness' and 'perceived ease of use' of a specific technology investment. 'Perceived benefits' has been used more recently in surveys (Harindranath, 2007) and in this context this research attempts to broaden the concept to 'perceived value' to give a broader perspective and attempt to capture more than just the one aspect from the company.

\section{Survey Findings and Discussion}

The categories in the final model were adjusted according to the findings of the survey and some elements were merged to take account of the responses. The educational 
Table 4. Summary of qualitative findings

\begin{tabular}{|c|c|c|}
\hline Category & Elements & Findings \\
\hline \multirow[t]{2}{*}{ Personal Factors } & $\begin{array}{l}\text { Educational } \\
\text { experience }\end{array}$ & $\begin{array}{l}\text { This factor was a major influ- } \\
\text { ence in all other research areas } \\
\text { related to SME growth and } \\
\text { successful adoption and is } \\
\text { again found to be a major in- } \\
\text { fluence within this research. } \\
\text { The presence of an ICT profes- } \\
\text { sional through experience (self- } \\
\text { taught) or through formal } \\
\text { education was influential in } \\
\text { success and also impacted the } \\
\text { next factor of knowledge of IT. }\end{array}$ \\
\hline & Knowledge of IT & $\begin{array}{l}\text { Although knowledge of ICT is } \\
\text { an important issue for all } \\
\text { companies, if that knowledge } \\
\text { of ICT has been gained } \\
\text { through the educational ex- } \\
\text { perience of the owner-man- } \\
\text { ager within ICT companies } \\
\text { that was found to have an im- } \\
\text { pact on both the company } \\
\text { turnover and successful adop- } \\
\text { tion. If an owner-manager } \\
\text { considered themselves to be } \\
\text { an ICT professional this also } \\
\text { had an impact on both turn- } \\
\text { over and perceived success. }\end{array}$ \\
\hline The Firm & Age, size, turnover. & $\begin{array}{l}\text { These three factors were ana- } \\
\text { lysed together and it was } \\
\text { found that there is sporadic } \\
\text { growth and no guarantee of } \\
\text { increased turnover as a com- } \\
\text { pany grows in terms of num- } \\
\text { ber of employees or years of } \\
\text { operation. Neither was there } \\
\text { any link between these factors } \\
\text { and adoption. Companies were } \\
\text { not more successful as they } \\
\text { grew in experience. }\end{array}$ \\
\hline
\end{tabular}


Table 4. (continued)

\begin{tabular}{|c|c|c|}
\hline & Turnover & $\begin{array}{l}\text { Turnover was also examined } \\
\text { alone and supports the fact } \\
\text { that owner-managers who are } \\
\text { degree holders have an in- } \\
\text { creased turnover in compari- } \\
\text { son with non-degree holders. } \\
\text { The discipline was irrelevant. }\end{array}$ \\
\hline \multirow[t]{4}{*}{$\begin{array}{l}\text { Organisational } \\
\text { readiness }\end{array}$} & Advice sought & $\begin{array}{l}\text { The advice sought is a major } \\
\text { influence on the success of the } \\
\text { adoption and in subsequent } \\
\text { implementation problems. } \\
\text { This study has again con- } \\
\text { firmed that most SMEs seek } \\
\text { advice from the circle of } \\
\text { known contacts. }\end{array}$ \\
\hline & $\begin{array}{lll}\text { Specialist skills in } \\
\text { company }\end{array}$ & $\begin{array}{l}\text { The specialist skills examined } \\
\text { here were the education of the } \\
\text { owner-manager and whether } \\
\text { that was formal or not and in } \\
\text { ICT or not. This appears to } \\
\text { have a major influence on } \\
\text { adoption success as it impacts } \\
\text { on both strategy and perceived } \\
\text { value, may be indicating the } \\
\text { presence of an ICT 'cham- } \\
\text { pion'. }\end{array}$ \\
\hline & Implementation issues & $\begin{array}{l}\text { The main implementation is- } \\
\text { sues measured here were sup- } \\
\text { plemented by asking what } \\
\text { support the companies re- } \\
\text { quired. These companies have } \\
\text { major implementation issues } \\
\text { and concerns regarding sup- } \\
\text { port and the availability of } \\
\text { consultancy support that can } \\
\text { be trusted. }\end{array}$ \\
\hline & Internal pressures & $\begin{array}{l}\text { Very few companies recog- } \\
\text { nised internal pressures al- } \\
\text { though this has been identified } \\
\text { as a barrier / enabler by other } \\
\text { researchers. This could indi- } \\
\text { cate that these companies are } \\
\text { very reactive and do not at- } \\
\text { tempt to drive forward the } \\
\text { adoption agenda in their own } \\
\text { company. }\end{array}$ \\
\hline
\end{tabular}


Table 4. (continued)

\begin{tabular}{|c|c|c|}
\hline External Pressures & $\begin{array}{l}\text { Influences on the pur- } \\
\text { chase. }\end{array}$ & $\begin{array}{l}\text { Main influences were seen as } \\
\text { customers and upgrades and } \\
\text { most upgrades were for cus- } \\
\text { tomers. Demonstrating a very } \\
\text { reactionary approach. }\end{array}$ \\
\hline & $\begin{array}{l}\text { Identification of ex- } \\
\text { ternal pressures in the } \\
\text { decision making proc- } \\
\text { ess }\end{array}$ & $\begin{array}{l}\text { Most do not recognise external } \\
\text { influences and when they do it } \\
\text { is predominately customers or } \\
\text { technology as above. }\end{array}$ \\
\hline \multirow[t]{2}{*}{ Strategy } & Reason for purchase. & $\begin{array}{l}\text { The main reasons for the pur- } \\
\text { chase are those cited as influ- } \\
\text { ences under External Pres- } \\
\text { sures. This demonstrates that } \\
\text { micro companies' strategy is } \\
\text { based on a reaction to either } \\
\text { customers or technology and } \\
\text { their reasoning does not ex- } \\
\text { tend beyond this. }\end{array}$ \\
\hline & $\begin{array}{l}\text { Significance of pur- } \\
\text { chase }\end{array}$ & $\begin{array}{l}\text { Most companies recognised } \\
\text { the significance of technology } \\
\text { being able to have an impact } \\
\text { on the way the business was } \\
\text { run. This may indicate that } \\
\text { whilst they may not 'do' strat- } \\
\text { egy there is willingness there } \\
\text { and an understanding of the } \\
\text { importance of technologies in } \\
\text { their business which may re- } \\
\text { quire some awareness raising. }\end{array}$ \\
\hline \multirow[t]{2}{*}{ Perceived Value } & Measures of success & $\begin{array}{l}\text { Most measures of success } \\
\text { were qualitative e.g. more } \\
\text { profit or more customers. No } \\
\text { companies use quantitative } \\
\text { measures. }\end{array}$ \\
\hline & Perception of success. & $\begin{array}{l}\text { Seen predominately as effi- } \\
\text { ciency or productivity gains. } \\
\text { However as no econometric } \\
\text { measures were used at all, this } \\
\text { is mainly based on instinct. }\end{array}$ \\
\hline
\end{tabular}

attainment of the owner-manager still remains the most direct influence on an SME, although increasingly in ICT, SMEs having an educated ICT Professional in the company also cast a major influence on the success of adoption of the company as a whole. Levels of decision making became of lesser importance within the model as the majority of owner-managers in the sample had made the decision themselves. "Advantage over 
traditional methods' was cited as an influence on investments along with other issues, it is therefore now incorporated as influences on the purchase rather than as a separate element.

Overall the issues arising would indicate a need to address the education of the owner-managers in the need to ensure that ICT purchases are aligned with their business needs. However as most micro SMEs see their strategy as being the next sale or the next customer this poses a particularly difficult field and business support actions are required for the ICT sector. The findings from the qualitative analysis are summarised in table 4. Those elements that companies did not consider to be a major influence have been removed from the model developed from the literature in table 3 . In conclusion a number of points were highlighted by this research:

The owner-manager's knowledge and education was highlighted as essential in successful adoption. The findings indicated that it in order to be successful in this sector, a high level of education may be necessary, with over $50 \%$ holding a first degree and $20 \%$ holding post graduate qualifications. It is suggested that high technological competence and understanding of advances in this area may be necessary, especially as $24 \%$ of the respondents had an IT related degree and overall $70 \%$ considered them selves to be an IT Professional. The companies who had an owner-manager formally educated in ICT also reported feeling less need to use technology to attract new customers as only $2 \%$ felt this need, and less internal pressure stemming from the need to enhance performance with only $14 \%$ reporting this. Although other variables may affect this process, a thorough grounding in ICT will help with evaluation of technology as a means to enhance business growth. Companies were often focused on one set of customers and tried to make technology investments 'fit' their business needs and their customer's needs.

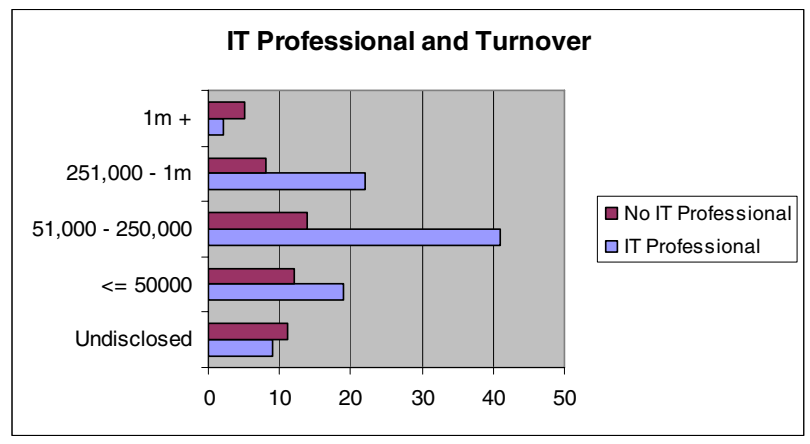

Fig. 2. IT professional vs Turnover for SMEs

Companies who had ICT professional skills in house had a higher turnover than those companies who did not. Also, those with no ICT Professional generally had a lower turnover (see Fig. 2). Previous research (Grandon et.al., 2004, Levy et al., 2005b, Van Akkeren and Cavaye, 1999, Thong and Yap, 1995, Iacovou, 1995, Rashid et al., 2001, Merhten et al., 2001, Storey, 1994) indicated that the presence of in-house skills is imperative in the successful adoption of technology. It would now appear that this also affects the growth in terms of turnover for ICT companies. It is 
believed that the sporadic rise and fall in turnover over time displayed by these companies may indicate how competitive the business environment is for ICT companies.

This research has again shown that most SMEs take their advice from friends and relatives $(10 \%)$, ICT store representatives $(12 \%)$, the Internet $(24 \%)$, etc. In all cases companies indicated that they used the source they felt was the most reliable although this was not always seen as trustworthy. However, 54\% stated they did not need advice, concerning the number of implementation problems encountered. This may mean that implementation problems could be exacerbated by the source of advice given prior to a decision to invest in new technologies that did not align well with the business model.

$49 \%$ of implementation problems were due to lack of appropriate skills; in particular, technological know-how (10\%) and third-party support (4\%) were a problem. This is a major anxiety and may indicate these companies' inability to support other sectors. There is a need for policy makers to address how these companies can be supported to enhance their support of other sectors. Of more concern is the fact that these ICT companies did not recognise their own problems in this area, with many companies claiming they would not require any advice on what to purchase. The same companies later in the survey explained the implementation problems encountered and their support needs. Many do not recognise that making recommendations to customers and selecting ICT for their own business infrastructure which align to the business model require a very different skill set.

The majority of companies do not evaluate purchases $(35 \%)$ or measure the success of those purchases (45\%), using 'gut instinct' to make a decision as to the success of an adoption. Where a measure was used it was a single factor, usually described as 'efficiency' and none used an econometric measure. Companies stated such measures as more profit, no complaints from the customers, more customers, efficiency and simply 'It Works'. This may indicate that many SMEs simply do not understand the importance of measuring success in order to guide future investment.

Business impact was cited most often (54\%) as the major impact afforded by adoption; this indicated that many found the adoption to have a major impact of how they conducted business. Many used ICT to develop their business and cited changes such as better communication, better customer demonstration facilities, a wider range of services, speedier software production etc. Again the indication from the findings is that the owner-manager education is imperative when recognising the significance of an adoption to the business, where significance indicates the subsequent impact of a purchase, with those formally educated in ICT indicating a more balanced approach to the drivers.

$53 \%$ of the companies did not acknowledge any external pressures in their purchasing decisions. As many companies are reactive rather than proactive it could mean that they are simply unaware of the need to be vigilant of the macro environment, merely reacting instead to the need to respond to customers, implement new legislation, etc. $39 \%$ of companies cited keeping up with technology advances by upgrading the software or hardware and this was seen as the main influence on investment. The reasons for upgrades were cited as increasing speed, improving efficiency, increasing reliability, expanding storage, network security, running more sophisticated software environments, adding wireless and broadband technologies. These upgrades were viewed as necessary as the SMEs were often catching-up with new technologies. 
Very few SMEs recognised the need to grow their business using new technological advances (1\%) which may mean they are unaware of technological advances outside their field of expertise.

Perceived value to most companies (39\%) is seen as being able to be more efficient. This was also cited as one of the main influences on the purchase, demonstrating that such companies can be very single-minded in their strategy with most still trying to increase efficiency and rarely focusing on innovative use or strategy. This leaves a very precarious situation for most companies as the perceived value of a purchase is explained in terms of its ability to increase efficiency. Yet, they do not subsequently measure that efficiency, citing instead the fact that they have had no complaints. The entire perception of success of an adoption, therefore, rests on the ability of the owner-manager to judge the successful increase in efficiency in a subjective manner. A number of issues are inherent in this and the need to increase the awareness of owner-managers about the importance of doing more than merely looking for the next sale will be a major hurdle to overcome.

Most companies also used a single 'perceived' measurement of success postimplementation. 39\% viewed the fact that they had achieved the implementation and that it was working as the measure. For $32 \%$ if profit or customers had increased also, then this was considered a success. However, they had rarely actually measured the increase in profit or the increase in customer numbers. This often led to the attitude that technology was merely a cost and something that needed to be implemented in order to 'stay in business'. This past experience with adoption leads to a less than positive approach to subsequent adoptions. This can lead to a cycle of adoption only when necessary as the perception is not supported by historical data.

\section{Conclusion and Conceptual Model Proposition}

The factors evaluated through this qualitative research are shown in a conceptual model (Fig. 3) which is based on the Van Akkeren and Cavaye (1999) model. This new model demonstrates the impact of the owner-managers perception on the ICT adoption process. The owner-manager makes ICT investment decisions by using their own perception of the value of the purchase as the main criteria in the pre-evaluation stage. Postadoption the owner-manager uses either the 'perception' of increased productivity, increased market share, or simply that 'it works' as a measure. This latter element has been missing from models published to date and forms the thrust of this conclusion. The suggestion is that the lack of historical data to feed into the next adoption situation means that the same mistakes are repeated, hence the feedback loop.

In this model the constraint variables are suggested as being those that impact the company in terms of size, sector, status and age, although those constraints are not directly tested through this research which concentrates on the ICT sector, this will prove to be constraints for further testing in other sectors. The moderator in this situation is seen as Government Intervention which has an opportunity to alter the course of adoption via funded initiatives and is also a factor which should be explored further, particularly in the wake of recent calls for closer collaboration between Government Department, Academics and Industry. The model is offered as a conceptual one that requires further evaluation to confirm or refute. 


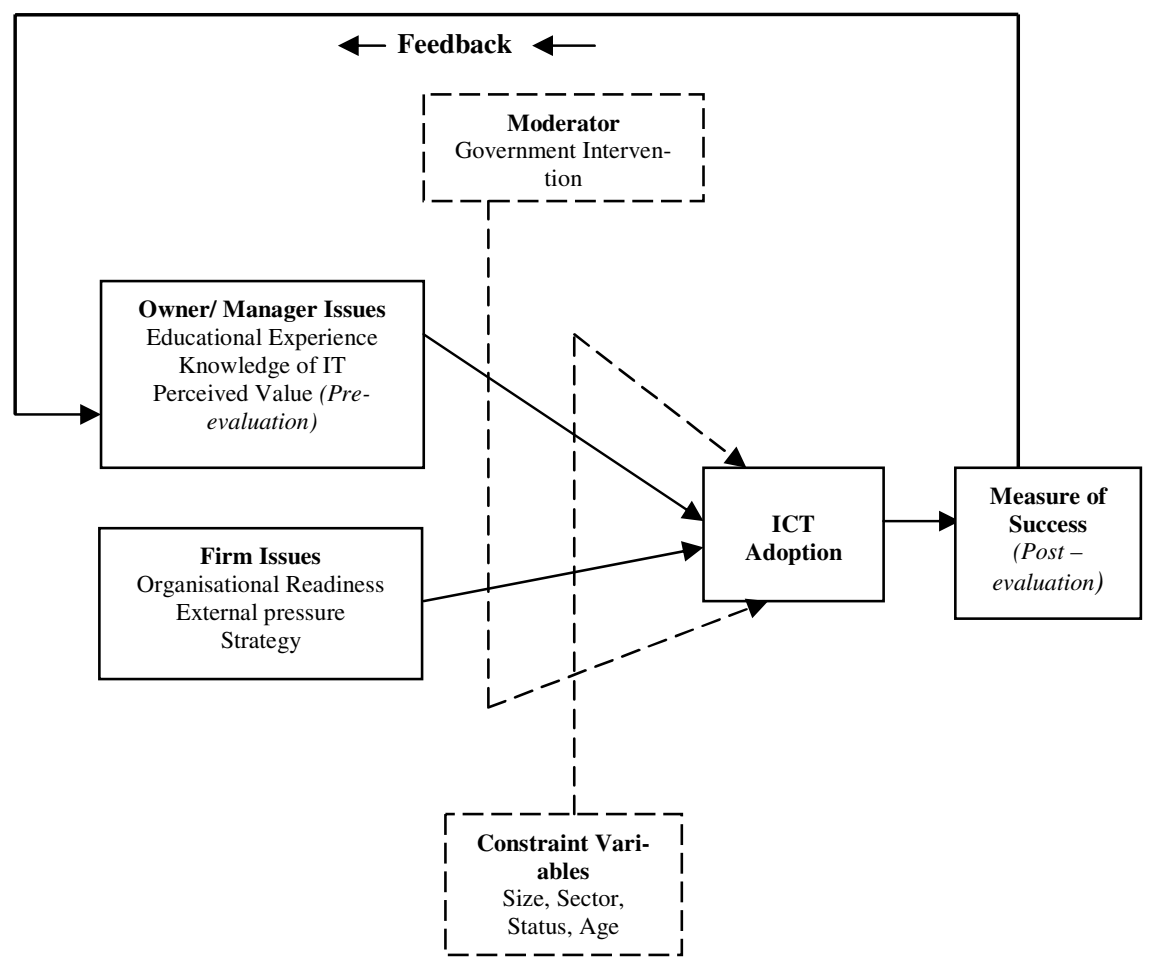

Fig. 3. Conceptual Model of ICT adoption in SMEs

Many past UK Government intervention initiatives concentrated on business support through Business Link, the Learning and Skills Council (LSC) and eSkills UK and ebusiness adoption initiatives. Most of this support is misguided and at the wrong level for these companies (Graham, 2007, Martin and Matlay, 2001), who not only need specific initiatives aimed at the technology related to the market they are in, but more basic support to help with implementation and adoption of IT. Currently they rely on instinct and/or customer-pressure which forces a situation which they then find costly and resource-intensive. They also need help in developing a feeling of trust, skills initiatives designed to improve their business and help with particular technological advances; including measures for evaluating technology more strategically.

The challenge therefore is two-fold. For Government initiatives, it is about recognising their role in the adoption process and that the main objective should be raising of awareness and embedding of appropriate skills within companies to endow them the ability to adopt successfully in the future. For academicians, overcoming the industry/academia divide and continuing this important quest should be prioritised. Especially as many academicians in this field have moved into other areas or, recognising that the issues are both complex and multi-layered have moved their work into the micro issues, leaving companies with no answers to their quandary. 


\section{References}

Ai-Qirim, N.A.Y. (ed.): Electronic commerce in small and medium-sized enterprises: frameworks, issues, and implications. Idea Group Publishing, Melbourne (2003)

Bagozzi, R.P., Davis, F.D., Warshaw, P.R.: Development and test of a theory of technological learning and usage. Human Relations 45(7), 660-686 (1992)

Bennett, R.J., Robson, P.: The market for external business advice services in Britain. In: Proceedings: 21st ISBA Conference Celebrating the Small Business, pp. 770-790 (1998)

Blackburn, R., Athayde, R.: Making the Connection, the Effectiveness of Internet Training in Small Businesses. Education and Training 42(4) (2000)

Bradford, M., Florin, J.: Examining the Role of Innovation Diffusion Factors on the Implementation Success of Enterprise Resource Planning systems. International Journal of Accounting Information Systems 4(3), 205-225 (2003)

Costello, P., Garner, S., Homer, G., Thompson, D.: Can the Internet Provide the West Midlands Automotive Industry with the Ultimate Lean Production Tool?-A Case Study of the Autolean Project. In: Proceedings: 2nd International SMESME Conference: Manufacturing and Business Systems Group University of Plymouth, March 29-31 (1999)

Costello, P., Moreton, R., Sloane, A.: IT Evaluation Frameworks - Do they make a valuable contribution? A critique of some of the classic models for use by SMEs. In: Proceedings of ECITE 2006: 13th European Conference on IT Evaluation University of Genova, Italy, September 28-29 (2006)

Costello, P., Chibelushi, C., Sloane, A.: ICT Adoption by ICT SMEs in the West Midlands the forgotten ICT Adopters. In: Proceedings of the 2nd European Conference on Information Management and Evaluation, Royal Holloway, University of London, UK, September 11-12 (2008)

Chwelos, P., Benbasat, I., Dexter, A.: Research Report: Empirical Test of an EDI Adoption Model. Information Systems Research 12(3), 304-321 (2001)

Culkin, N., Smith, D.: An Emotional Business: A Guide to Understanding the Motivations of Small Business Decision Makers. Qualitative Market Research: An International Journal 3(3), 145-157 (2000)

Davis, D., Bagozzi, R., Warshaw, P.: User acceptance of computer technology: a comparison of two theoretical models. Management Science 35(8), 982-1003 (1989)

Fishbein, M., Ajzen, I.: Belief, attitude, intention, and behavior: An introduction to theory and research. Addison-Wesley, Reading (1975),

http: / /www. people.umass. edu/aizen/f\&a1975.html

(Date accessed: 15/07/2007)

Grandon, E., Pearson, J.M.: Electronic Commerce Adoption: An Empirical Study of Small and Medium US Business. Information \& Management 42, 197-216 (2004)

Graham, F.: The Skills Survey 2007: A report into Skills for Enterprise and Growth for the ICT Cluster by Red Box Research (June 2007)

Harindranath, G., Barnes, D., Dyerson, R.: ICT Adoption and use in UK SMEs. In: Proceedings: The European Conference on Information Management and Evaluation, University of Montpellier 1, Montpellier, France, September 20-21 (2007)

Husein, T., Moreton, R., Sloane, A.: Electronic Commerce: A consideration of implementation for SMEs. Journal of Management Studies 5(1), 77-83 (1996)

Iacovou, A.L., Benbara, I., Dexter, A.S.: Electronic data Interchange, Small Organisations; Adoption and Impact of Technology. MIS Quarterly 19(4), 465-485 (1995)

Jackson, M., Sloane, A.: A Model for analysing the success of adopting new technologies focusing on electronic commerce. Business Process Management Journal 13(1), 121-138 (2007) 
Kai-Uwe Brock, J.: Information and Technology in the Small Firm. Prentice Hall/Pearson Education, Englewood Cliffs (2000)

King-Turner, M., Bonnett, M.: Adoption of Open Source in SMEs: Lessons from the Front Line. Session in O'Reilly European Open Source Convention, Amsterdam (October 19, 2005)

Lauder, G., Westhall, A.: Small Firms Online. Commision on Public Policy in British Business, 6 (1997)

Lefebvre, E., Lefebvre, L.: Information and Communication Technologies: The Impact of Their Adoption on Small and Medium-sized Enterprises. IDRC Booktique ORDI (1996)

Levy, M., Powell, P.: Strategies for Growth in SMEs. The Role of Information and Information Systems. Elsevier Butterworth Heinmann, Oxford (2005a)

Levy, M., Powell, P., Worrall, L.: Strategic Intent and E-business in SMEs: Enablers and Inhibitors. Information Resources Management Journal 18(4), 1-20 (2005b)

Macgregor, R.C., Vrazalic, L.: A Basic Model of Electronic Commerce Adoption Barriers, A study of regional small businesses in Sweden and Australia. Journal of Small Business and Enterprise Development 12(4), 510-527 (2005)

Martin, L., Matlay, H.: Blanket approaches to promoting ICT in small firms: some lessons from the DTI ladder adoption model in the UK. Internet Research: Electronic Networking Applications and Policy 11(5), 399-410 (2001), http: / / www . emerald-library . com/ft (Date accessed: 2/03/2002)

Mehrtens, J., Cragg, P., Mills, A.: A model of internet adoption by SMEs. Information \& management 39(3), 165-176 (2001)

Mercer, D.: Industry Scenarios: short-termism revealed. Industrial Management \& Data Systems 96(8), 23-27 (1996)

Nathalie, N.M., Marsh, A.: Small Business and Information Technology: Risk, Planning and Change. Journal of Business and Enterprise Development 5(3), 228-245 (1998)

Premkumar, G., Roberts, M.: Adoption of new information technologies (1999); Rashid, M.A., Al-Qirim, N.A.: E-Commerce Technology Adoption Framework by New Zealand Small to Medium Enterprises. Research Letters in the Information and Mathematical Sciences 2(1), 63-70 (2001)

Rogers, E.M.: Diffusion of Innovations, 5th edn. Free Press, New York (2003)

Sarosa, S., Zowghi, D.: Strategy for adopting information technology for SMEs: Experience in adopting email within an Indonesian furniture company. Electronic Journal of Information Systems Evaluation 6(2), 165-176 (2003)

Sheppard, S., Hooton, S.: Regional Economic Impact of ICTs and the Role of RDAs/DAs. A White Paper: Informing the Policy Debate. Adroit Economics Ltd. (2007)

Thong, J.Y.L., Yap, C.S.: An information technology adoption model for small businesses. In: Proceedings: IFIP WG8.6 Working Conference on Diffusion and Adoption of Information Technology, Leangkollen, Oslo, Norway, October 14-17, 1995, pp. 429-442 (1995)

Storey, D.: Understanding the Small Business Sector. Thomson Business Press, London (1994)

Tornatzky, L.G., Klein, K.J.: Innovation characteristics and innovation adoption implementation: a meta-analysis of findings. IEEE Transactions on Engineering Management 29(1), 28-45 (1982)

Van Akkeren, J., Cavaye, A.: Factors Affecting Entry-Level Internet Technology Adoption by Small Business in Australia: An Empirical Study. In: Proceedings: 10th Australasian Conference on Information Systems, pp. 1716-1728. Victoria University of Wellington, New Zealand (1999)

Venkatesh, V., Davis, F.D.: A theoretical extension of the technology acceptance model: Four longitudinal field studies. Management Science 46(2), 186-204 (2000)

Venkatesh, V., Morris, M., Davis, G., Davies, F.: User Acceptance of Information Technology: Toward a Unified View. MIS Quarterly 27(3), 425-478 (2003) 